\title{
Use of elemental sulphur as an acidifying soil amendment for Brassica napus cultivation
}

\begin{abstract}
Utilización de azufre elemental como enmienda ácida en suelos para el cultivo de Brassica napus Utilização de enxofre elementar como agente acidificante do solo na cultura de Brassica napus
\end{abstract}

\section{AUTHORS}

\section{López-Mosquera}

M.E. @,1

melvira.lopez@usc.es

López-Fabal A. ${ }^{2}$

\section{Illera Vives M. ${ }^{1}$}

Seoane Labandeira S. ${ }^{3}$

@ Corresponding Author

${ }^{1}$ Instituto de

Biodiversidade Agraria e Desenvolvemento

Rural (IBADER).

Universidad de Santiago de Compostela. Campus Universitario. 27002

Lugo, Spain.

${ }^{2}$ Departamento de Produción Vexetal. Universidad de Santiago de Compostela. Campus Universitario. 27002

Lugo, Spain.

${ }^{3}$ Departamento de Edafoloxía e Química Agrícola. Universidad de Santiago de Compostela. Campus Universitario. 27002 Lugo, Spain.
Received:13.11.2014 | Revised: 13.04.2015 | Accepted: 23.04.2015

\section{ABSTRACT}

\section{ABSTRACT}

Elemental sulphur is applied to alkaline soils as an acidifying material in order to improve nutrient availability and soil productivity. The oil industry extracts crude oils with ever higher concentrations of sulphur (S) that should not be released to the atmosphere and can be recovered by desulphurisation processes. The elemental S thus obtained has diverse applications, such as the manufacture of sulphuric acid, retreaded tyres, fungicides and acidifying agents. When used as a soil acidifying agent, $\mathrm{S}$ undergoes an oxidation process that depends on several soil-related factors: temperature, aeration, texture and organic matter content. The most important parameter appears to be the particle size of the $\mathrm{S}$ form applied to the soil. This study investigated the acidifying effects of two forms of elemental S, derived from an oil refinery, on an alkaline soil planted with oilseed rape. A trial was established in $300 \mathrm{~L}$ containers maintained outdoors in a site that received more than $1000 \mathrm{~mm}$ of precipitation during the study period, between October and the end of April. The treatments consisted of powdered $(<0.5 \mathrm{~mm}) \mathrm{S}$ at a dose of $1.5 \mathrm{t} \mathrm{ha}^{-1}$, and sieved $(0.5-2 \mathrm{~mm}) \mathrm{S}$ at doses of 3 and $5 \mathrm{tha}^{-1}$. Control soils were not treated with sulphur. The effects of the different treatments were studied by analysing leachates collected after every episode of rain during the crop cycle, foliar analysis of the crop produced, quantification of seed production and oil yield, and, finally, analysis of aqueous extracts of the soil obtained after harvesting the crop. The results obtained show that under the study conditions, sieved $\mathrm{S}(0.5-2 \mathrm{~mm})$ was at least as effective as powdered $\mathrm{S}$ as a treatment for acidifying the alkaline calcareous soil used in the study. The sieved form offers two advantages relative to the powdered form: it requires less grinding and its storage and distribution in the field are simpler because the material does not disperse in the air (as the particles are larger) and is not explosive.

\section{RESUMEN}

Para mejorar la disponibilidad de nutrientes e incrementar su nivel productivo en los suelos alcalinos se aplican materiales de naturaleza acidificante, como es el caso del azufre (S) elemental. En la industria del petróleo cada vez se tratan crudos con mayor contenido en azufre, elemento que no debe ser enviado a la atmósfera y que puede ser recuperado a través de procesos de desulfuración. El S elemental asi obtenido tiene diversas aplicaciones como fabricación de ácido sulfúrico, recauchutados, fungicidas, enmiendas acidificantes, entre otros. Cuando se utiliza como enmienda acidificante del suelo, el $S$ sufre un proceso de oxidación que depende de varios factores: temperatura, humedad, aireación, textura y contenido en materia orgánica pero, desde el punto de vista del manejo, es el tamaño de partícula del $S$ aplicado el parámetro que parece tener mayor importancia. En este trabajo se estudió el efecto acidificante de dos formatos de $S$ elemental procedente de una industria de refinado de petróleo, sobre un suelo alcalino cultivado con colza. En contenedores de 300 litros situados al aire libre se estableció un ensayo en una localidad con una pluviometría que superó los $1000 \mathrm{~mm}$ en el periodo comprendido entre octubre y finales de abril. Los tratamientos de azufre ensayados fueron: $S$ en polvo $(<0.5 \mathrm{~mm})$ en dosis de $1,5 \mathrm{th} \mathrm{h}^{-1}$; $S$ cribado $(0,5-2 \mathrm{~mm})$ 
en dosis de 3 y 5 tha a $^{-1}$ y un control sin aplicación de azufre. Para el seguimiento del ensayo se recogieron aguas de drenaje tras los episodios de lluvia ocurridos a lo largo del ciclo de cultivo, se hizo análisis foliar, se cuantificó la producción de semilla y el rendimiento de aceite y finalmente se analizó el extracto acuoso del suelo tras la cosecha. Los resultados obtenidos permiten afirmar que, en las condiciones de este trabajo, los tratamientos de azufre cribado (0,5-2 mm) resultaron tanto o más efectivos que el de azufre polvo para la acidificación de suelos calco-alcalinos. El formato cribado presenta una doble ventaja respecto del polvo: requiere menor molienda y su almacenamiento y distribución en campo resultan más sencillas, ya que por su mayor tamaño no flota en el aire y no resulta explosivo.

\section{RESUMO}

$O$ enxofre elementar é aplicado aos solos alcalinos como agente acidificante com o objetivo de melhorar a sua disponibilidade em nutrientes e aumentar a sua produtividade. Na indústria do petróleo extraem-se óleos brutos cada vez com maior conteúdo em enxofre, elemento que não deve ser lançado na atmosfera e que pode ser recuperado através de processos de dessulfurização. O S elementar assim obtido tem diversas aplicações como o fabrico de ácido sulfúrico, pneumáticos recauchutados, fungicidas, corretivos acidificantes, entre outros. Quando se utiliza como agente acidificante do solo, o S sofre um processo de oxidação que depende de vários fatores: temperatura, humidade, arejamento, textura e conteúdo em matéria orgânica. Contudo o parâmetro mais importante parece ser a dimensão das partículas do S aplicado. Neste trabalho estudou-se o efeito acidificante de duas formas de S elementar procedentes de uma refinaria de petróleo, aplicadas a um solo alcalino cultivado com colza. Instalou-se um ensaio em contentores de 300 litros localizados ao ar livre numa localidade com uma pluviometria que ultrapassou os 1000 mm no período compreendido entre outubro e finais de abril. Os tratamentos de enxofre testados foram: $S$ em pó $(<0.5 \mathrm{~mm})$ numa

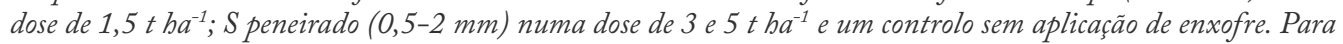
a monitorização do ensaio recolheram-se as águas de drenagem após os episódios de chuva ocorridos ao longo do ciclo da cultura, procedeu-se à análise foliar, quantificou-se a produção de sementes e o rendimento de oleo e finalmente analisou-se o extrato aquoso do solo após a colheita. Os resultados obtidos permitem afirmar que, nas condições do ensaio, os tratamentos de enxofre peneirado $(0,5-2 \mathrm{~mm})$ resultaram tão ou mais efetivos que os de enxofre pó para a acidificação de solos calcário-alcalinos. A forma de enxofre peneirada apresenta uma dupla vantagem relativamente ao enxofre em pó: requer menor moenda e o seu armazenamento e distribuição no campo resulta mais fácil, porque as suas particulas são de maior dimensão não se dispersando no ar e não é explosivo.

\section{Introduction}

Soils classified as basic or slightly alkaline pose a problem for agricultural production. From the chemical point of view, the low availability of certain nutrients such as phosphorus, boron, iron, manganese, copper and zinc are emphasized. These soils also contain highly available calcium and magnesium, which may give rise to nutritional imbalances (Brady and Weil 2010). Acidifying materials have been applied to alkaline soils since the 1960s in order to prevent such problems. Although sulphuric acid, phosphoric acid and urea can be combined with different acids for this purpose, elemental sulphur is the oldest and most commonly used acidifying material (Miyamoto 1998). When sulphur is added to soil it undergoes chemical and microbial oxidation, generating sulphuric acid and a consequent decrease in $\mathrm{pH}$ (Zhihui et al. 2008). The process is affected by soil temperature (oxidation occurs rapidly at $>25^{\circ} \mathrm{C}$ and is minimal at $<5^{\circ} \mathrm{C}$ ), moisture content and aeration (Janzen and Bettany 1987), as well as texture and organic matter content (Byoung-Ho and Chung 2011). However, the sulphur particle size is considered to be the most important factor, to the extent that Janzen and Bettany (1987) suggested expressing the dose applied in 
relation to the specific surface area rather than the weight of sulphur.

Elemental $\mathrm{S}$ is mainly produced as an inert byproduct of the desulphurisation of combustible liquids (petrol and diesel) and gases (natural gas) in oil refineries. The forms of sulphur available in oil refineries are prill (3-5 $\mathrm{mm}$ ) and cake (6.3-12.5 mm), from which $\mathrm{S}$ is released too slowly for use as soil amendment because of the large particle size. These forms can be ground to produce powdered $\mathrm{S}$ (particle size $<0.5 \mathrm{~mm}$ ), which is more reactive in soil but also more expensive and has the disadvantage of being explosive, particularly when used in large quantities. There is therefore a clear need for new products that combine the high reactivity of powdered $S$ and the low risk and cost of forms with larger particle size.

Oilseed rape is the second most common oilbearing crop in the world, after soyabean, and the European Union is the highest producer and consumer of the crop worldwide. Within the EU, Germany produces most oilseed rape (5.5 million tonnes per year) followed by France ( 4.9 million tonnes per year) and the UK and Poland (both 2.5 million tonnes per year); together these four countries produce $75 \%$ of the total production in the EU (Maluenda 2014). In Spain, 28.757 ha of land was dedicated to oilseed rape in 2012, yielding 53.447 tonnes of the crop. Production was highest in Castilla-León, generating 50\% of the national production (MAGRAMA 2012). This crop is not only of interest for human consumption, but also for biofuel production. Oilseed rape can be grown in soils with a wide range of $\mathrm{pH}$, although the preferred range is 5.5-7.0. It is an oil-bearing crop with high nitrogen and sulphur requirements (Jackson 2000). Sulphur favours and stimulates the adsorption of nitrogen during flowering and seed formation; it also participates in the synthesis of glucosilonates and determines the amount and type of fatty acids formed (Fismes et al. 2000).

The aims of this study were to compare the capacity of two forms of elemental sulphur of different particle sizes to acidify a slightly alkaline soil, and to compare the effects on grain and oil yields from an oilseed rape crop.

\section{Material and Methods}

The trial was established in an experimental plot on the university campus in Lugo (Galicia, NW Spain; 42 $59^{\prime} 33^{\prime \prime} \mathrm{N}$ and $7^{\circ} 32^{\prime} 48^{\prime \prime} \mathrm{W}$ ) in September 2012. The cultivation medium was an alkaline soil from Dueñas (Palencia, Spain), with a loam-clay-sandy texture, $\mathrm{pH}$ in water (1:2.5) of 8.7 , EC (1:5) of $0.15 \mathrm{dS} \mathrm{m}^{-1}, 24.8 \%$ carbonate, $0.58 \%$ organic matter, $5.6 \mathrm{mg} \mathrm{kg}^{-1}$ $\mathrm{P}$ Olsen, $57.62 \mathrm{mg} \mathrm{kg}^{-1}$ available $\mathrm{K}$, and cation exchange content, (expressed in $\mathrm{cmol}_{(+)} \mathrm{kg}^{-1}$ ) of 30.91 for $\mathrm{Ca}^{+2}$; 1.29 for $\mathrm{Mg}^{+2}$; 0.07 for $\mathrm{Na}^{+}$; and 0.15 for $\mathrm{K}^{+}$.

The $\mathrm{S}$ forms tested were derived from an oil desulphurisation process carried out at the Repsol Oil Refinery in La Coruña (Spain). Two forms were used: commercial powdered S (PS), of particle size $<0.5 \mathrm{~mm}$, and sieved $S$ (SS), produced in the laboratory by grinding and sieving prill (supplied by the aforementioned refinery) to particle size $0.5-2 \mathrm{~mm}$.

The trial was conducted in 12 high density polythene containers of capacity $300 \mathrm{~L}$ and fitted with drainage pipes for the collection of leachates. A layer (5 cm thick) of quartz gravel (previously washed) was placed in each container; a sheet of geotextile fabric was placed on top of the gravel to prevent soil loss, and finally a layer $40 \mathrm{~cm}$ of untreated soil was placed on the top the fabric. Compost made from horse and rabbit manure [pH: 9.3 and total element content expressed as a percentage dry matter $(\mathrm{C}: 25.3, \mathrm{~N}: 1.8, \mathrm{P}: 1.1$, $\mathrm{K}: 1.9)]$ was added to the soil $\left(90 \mathrm{t} \mathrm{ha}^{-1}\right)$, simulating tillage to a depth of $30 \mathrm{~cm}$, to increase the amount of organic matter to at least $3 \%$, improve the physical properties and as the only background fertilizer. The initial soil thus contained $3.5 \%$ organic matter and the $\mathrm{pH}$ was 8.2.

Four treatments were applied at random in triplicate containers. Each treatment was characterized by the form and dose of sulphur supplied [SP1.5: powdered S, $1.5 \mathrm{t} \mathrm{ha}^{-1}$; SC3: sieved S (0.5-2 mm) $3 \mathrm{t} \mathrm{ha}^{-1}$; SC5: sieved S (0.5-2 mm) $\left.5 \mathrm{t} \mathrm{ha}^{-1}\right]$ and a control without sulphur (C). Previous experimental studies carried out by Repsol S.A./ Rlesa in this type of soil and with different crops showed that a dose of $1.5 \mathrm{t} \mathrm{ha}^{-1}$ powdered $S$ was effective as an acidifying agent 
(Repsol S.A. Petróleo/ Rlesa, pers comm), while higher doses were difficult to handle because of the powdery and explosive nature of the material. In this trial, the recommended dose of $1.5 \mathrm{t} \mathrm{ha}^{-1}$ was used for the powdered form, and higher doses of the sieved $S$ were tested as this form was expected to be less reactive due to the larger particle size. The dose of $\mathrm{S}$ used for each treatment was applied to the soil surface and mixed with the upper $5 \mathrm{~cm}$ of soil. The doses used are within the range of 1.5 to $6 \mathrm{tha}^{-1}$, used by Byoung-Ho and Chung (2011).

The traditional "NK Passion" cultivar of autumn oilseed rape (Brassica napus var. oleifera (Moench) D.C.) was selected for the study. The crop was sown on 4 October 2012, at a density of $10 \mathrm{~kg} \mathrm{ha}^{-1}$, and $100 \mathrm{~kg}$ of $\mathrm{N} \mathrm{ha}^{-1}$ was applied as fertilizer (as $20.5 \%$ calcium ammonium nitrate) in two doses: $25 \mathrm{~kg} \mathrm{~N} \mathrm{ha}^{-1}$ in March and $75 \mathrm{~kg} \mathrm{~N} \mathrm{ha}^{-1}$ in April 2013.

Soil samples were obtained from each container, at a depth of $0-20 \mathrm{~cm}$, after harvesting the plants. The soil samples were air-dried and passed through a $2 \mathrm{~mm}$ sieve before determining the $\mathrm{pH}$ in water (soil:water ratio of 1:2.5) and the sulphate and phosphate contents of aqueous extracts of the samples (soil:water ratio, 1:5 w:v), following the methods described by Bardsley and Landcaster (1960) and Olsen and Sommers (1982) respectively.

The precipitation data were recorded at the weather monitoring station located in the university campus in Lugo ( $42^{\circ} 59^{\prime} 42^{\prime \prime} \mathrm{N}$ and $7^{\circ} 32^{\prime} 40^{\prime \prime} \mathrm{W}$, elevation, $400 \mathrm{~m}$ ), very close to where the study was carried out. The accumulated precipitation between October 2012 and April 2013 was 1019 mm. Leachates were also collected from the containers during this period after rainfall events (11 samples). These samples were analysed to determine the $\mathrm{pH}$ and the $\mathrm{SO}_{4}{ }^{2-}$ and $\mathrm{PO}_{4}{ }^{3-}$ contents, following the same methods used with the 1:5 aqueous soil extract.

Samples of the most recently mature leaves were collected from the plants before flowering (Haneklaus and Schnug 1991), for determination of total N, P, K, Ca, Mg, S, Fe, Mn, Cu, Zn, Mo and $B$ (Chapman and Pratt 1961). At the end of the crop cycle (July 2013), the grain was weighed and the soil yield was quantified according to the method outlined in RD 2257/1994 (BOE 1995).

Data were examined for treatment effects by one-way analysis of variance (ANOVA). Prior to the ANOVA, the normality and homogeneity of the variances were checked by the KolmogorovSmirnov and Levene tests, respectively. Significant differences between the treatment means were calculated by the Tukey test, at $p<0.05$. All analyses were performed with SPSS software, version 20.0 .

\section{Results}

The $\mathrm{pH}$ and the sulphate and phosphate contents of the leachates collected after the rainfall events are summarized in Figure 1. All $\mathrm{S}$ treatments lowered the $\mathrm{pH}$ of the test soils, relative to that of the control soil. Thus, at the first sampling time, the $\mathrm{pH}$ was significantly lower in all treated soils than in the control soil, but with no difference between the treated soils. In the last three months, the $\mathrm{pH}$ of the leachates from the S-treated soils increased until there was no significant difference between the treated soils. The change in $\mathrm{pH}$ is associated with the generation of sulphates and release of phosphates. The sulphate and phosphate contents were lower in the control leachate than in the leachates from the S-treated soils. The highest sulphate and phosphate contents were found in the leachates from the soil treated with sieved S, especially at the highest dose.

Analysis of the soluble phase of the soil (1:5 extract, w:v), obtained ten months after sowing (Table 1), indicated that in all $\mathrm{S}$ treatments the soil $\mathrm{pH}$ was lower than in the control, although the difference was only significant for the sieved S (Table 1). The $\mathrm{pH}$ was also significantly lower in the soil treated with sieved $\mathrm{S}$ than in the soil treated with powdered $\mathrm{S}$. The observed decrease in $\mathrm{pH}$ was 0.34 units for the powdered $\mathrm{S}$ and 0.9-1.2 units for the sieved $\mathrm{S}$. 

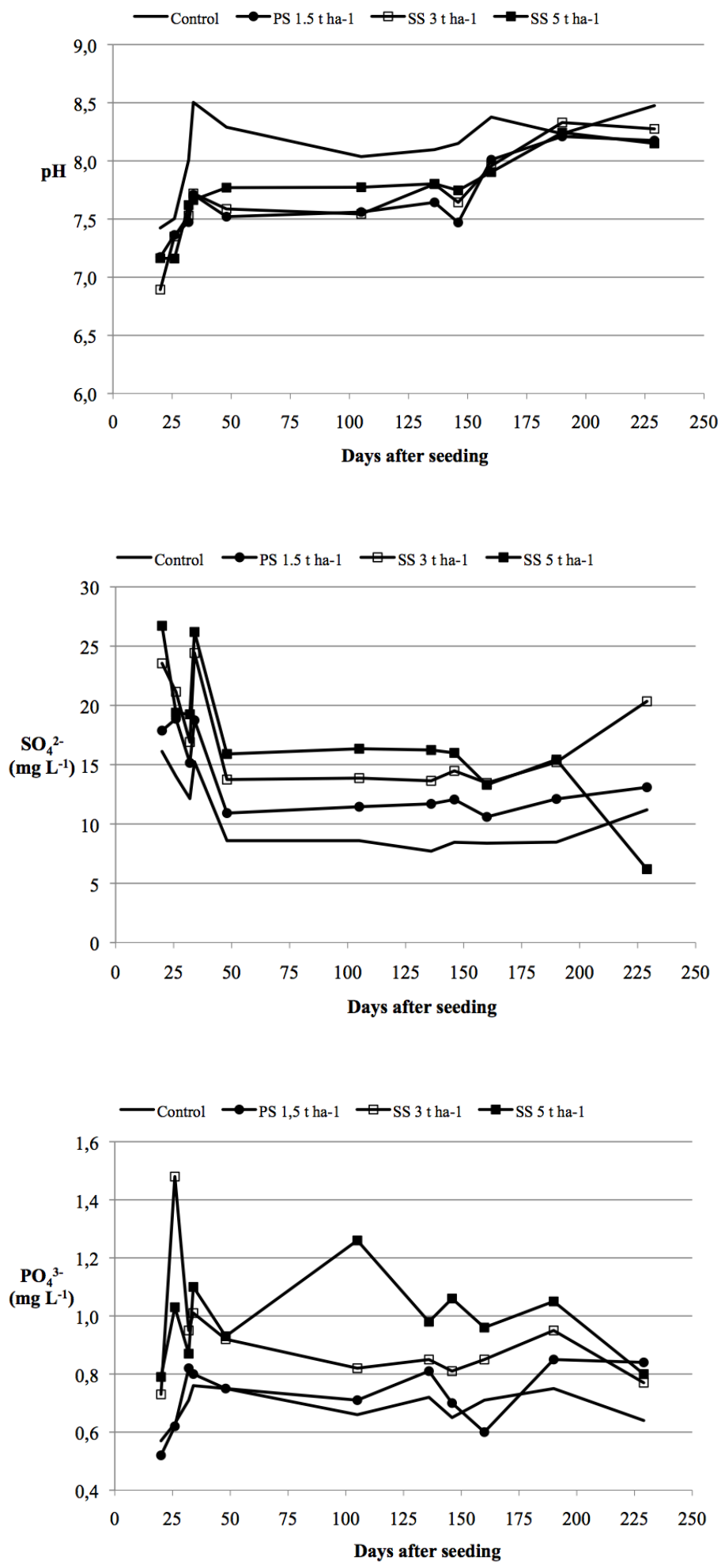

Figure 1. Changes in $\mathrm{pH}$, sulphate and phosphate contents $\left(\mathrm{mg} \mathrm{L}^{-1}\right)$ of the leachates during the rainy period (autumn-spring) of the oilseed rape production cycle. PS: Powdered S; SS: Sieved S. 
As expected, the sulphate contents were higher in the S-treated soils, lower in the soils treated with PS, and highest in those treated with SS, especially at the highest dose $\left(5 \mathrm{t} \mathrm{ha}^{-1}\right)$. The decrease in soil $\mathrm{pH}$ favoured phosphate solubility; however, there was no significant difference between the phosphate content in the soils treated with powdered $S$ and in the control soil. The soils treated with sieved $\mathrm{S}$ contained the highest levels of phosphate, although the difference was only significant for the highest dose of sulphur (SS5).

Table 1. Mean values and standard deviations of $\mathrm{pH}(1: 2.5)$, and sulphate and phosphate contents of the soil:water extract (1:5, w:v) on harvesting the oilseed rape (10 months after application of the treatments). In each row, values indicated by different letters are significantly different at $p<0.05$

\begin{tabular}{lcccc} 
& Control & $\begin{array}{c}\text { Powdered S } \\
1.5 \mathrm{t} \mathrm{ha}^{-1}\end{array}$ & $\begin{array}{c}\text { Sieved S } \\
3 \mathrm{t} \mathrm{ha}\end{array}$ & $\begin{array}{c}\text { Sieved S } \\
5 \mathrm{t} \mathrm{ha}^{-1}\end{array}$ \\
\hline $\mathbf{p H}$ & $8.18 \pm 0.12 \mathrm{c}$ & $7.84 \pm 0.23 \mathrm{bc}$ & $6.96 \pm 0.58 \mathrm{a}$ & $7.25 \pm 0.10 \mathrm{ab}$ \\
$\mathbf{S O}_{4}{ }^{2-}\left(\mathbf{m g ~ L}^{-1}\right)$ & $44.1 \pm 2.30 \mathrm{a}$ & $56.4 \pm 4.24 \mathrm{~b}$ & $71.4 \pm 4.10 \mathrm{c}$ & $80.6 \pm 2.57 \mathrm{~d}$ \\
$\mathbf{P O}_{4}{ }^{3-}\left(\mathbf{m g ~ L}^{-1}\right)$ & $1.83 \pm 0.09 \mathrm{a}$ & $1.83 \pm 0.02 \mathrm{a}$ & $2.37 \pm 0.01 \mathrm{ab}$ & $2.85 \pm 0.24 \mathrm{~b}$ \\
\hline
\end{tabular}

Adsorption of nutrients by the plants, relative to the control, was only significantly different in the case of sulphur, the concentration of which was higher in plants grown in amended soils, especially those amended with the powdered
S. For the micronutrients, the only differences observed were in the adsorption of molybdenum, which was highest in the control soils, in which the high $\mathrm{pH}$ favoured the availability of this element (Table 2).

Table 2. Foliar nutrients in the oilseed rape plants before flowering. In each row, values indicated by different letters are significantly different at $p<0.05$

\begin{tabular}{|c|c|c|c|c|}
\hline & Control & $\begin{array}{c}\text { Powdered S } \\
1.5 \mathrm{t} \mathrm{ha}^{-1}\end{array}$ & $\begin{array}{l}\text { Sieved S } \\
3 \mathrm{t} \mathrm{ha}^{-1}\end{array}$ & $\begin{array}{l}\text { Sieved S } \\
5 \mathrm{t} \mathrm{ha}^{-1}\end{array}$ \\
\hline N (\%) & $1.8 \pm 0.09 a$ & $1.8 \pm 0.01 a$ & $1.8 \pm 0.08 a$ & $1.8 \pm 0.02 a$ \\
\hline P (\%) & $0.3 \pm 0.03 a$ & $0.3 \pm 0.05 a$ & $0.3 \pm 0.04 a$ & $0.3 \pm 0.03 a$ \\
\hline K (\%) & $0.8 \pm 0.05 a$ & $0.6 \pm 0.39 a$ & $0.7 \pm 0.07 a$ & $0.7 \pm 0.24 a$ \\
\hline $\mathrm{Ca}(\%)$ & $0.3 \pm 0.10 \mathrm{~b}$ & $0.2 \pm 0.10 \mathrm{ab}$ & $0.1 \pm 0.02 \mathrm{ab}$ & $0.1 \pm 0.09 a$ \\
\hline Mg (\%) & $0.07 \pm 0.03 a$ & $0.03 \pm 0.02 a$ & $0.04 \pm 0.00 \mathrm{a}$ & $0.04 \pm 0.02 a$ \\
\hline S (\%) & $0.4 \pm 0.01 a$ & $0.6 \pm 0.03 \mathrm{c}$ & $0.5 \pm 0.02 b$ & $0.5 \pm 0.03 b$ \\
\hline$B\left(\mathbf{m g ~ k g}^{-1}\right)$ & $18.5 \pm 0.90 a$ & $16.5 \pm 2.00 \mathrm{a}$ & $19.7 \pm 3.30 \mathrm{a}$ & $18.2 \pm 3.50 \mathrm{a}$ \\
\hline $\mathrm{Cu}\left(\mathrm{mg} \mathrm{kg}^{-1}\right)$ & $17.8 \pm 14.80 a$ & $12.5 \pm 14.50 \mathrm{a}$ & $13.6 \pm 13.50 \mathrm{a}$ & $13.6 \pm 12.50 \mathrm{a}$ \\
\hline $\mathrm{Fe}\left(\mathrm{mg} \mathrm{kg}^{-1}\right)$ & $180.0 \pm 118.30 a$ & $116.4 \pm 31.60 a$ & $92.0 \pm 7.90 \mathrm{a}$ & $60.1 \pm 41.20 a$ \\
\hline Mn (mg kg-1) & $30.6 \pm 0.60 a$ & $31.0 \pm 4.10 a$ & $29.3 \pm 3.00 \mathrm{a}$ & $34.6 \pm 5.30 a$ \\
\hline Mo (mg kg-1) & $7.1 \pm 0.50 c$ & $0.5 \pm 0.07 a$ & $1.4 \pm 0.05 b$ & $1.0 \pm 0.14 \mathrm{ab}$ \\
\hline $\mathrm{Zn}\left(\mathrm{mg} \mathrm{kg}^{-1}\right)$ & $50.7 \pm 28.10 \mathrm{a}$ & $38.6 \pm 1.00 a$ & $40.8 \pm 5.00 a$ & $40.5 \pm 3.60 a$ \\
\hline
\end{tabular}


Regarding the grain and oil production, treatment with the highest dose of sieved $\mathrm{S}\left(5 \mathrm{t} \mathrm{ha}^{-1}\right)$ led to the highest grain yield (4853 $\left.\mathrm{kg} \mathrm{ha}^{-1}\right)$, which was significantly different from that in the other $\mathrm{S}$ treatments and the control (Figure 2). The same occurred with the oil content of the seed, which was significantly higher for the treatment with the highest dose of sieved $S\left(2008 \mathrm{~kg} \mathrm{ha}^{-1}\right)$ than for the other treatments and the control. These values are similar to those reported by Fismes et al. (2000) for calcareous soils in France.

Dry weight of grain $\left(\mathrm{kg} \mathrm{ha}^{-1}\right)$

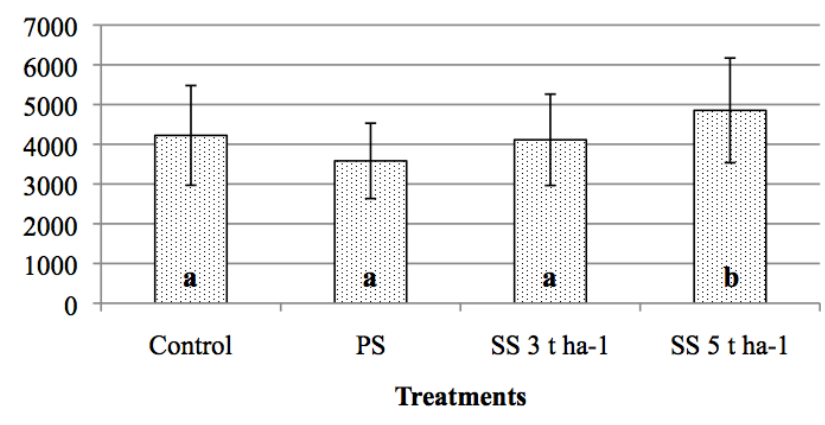

Oil $\left(\mathbf{k g ~ h a}^{-1}\right)$

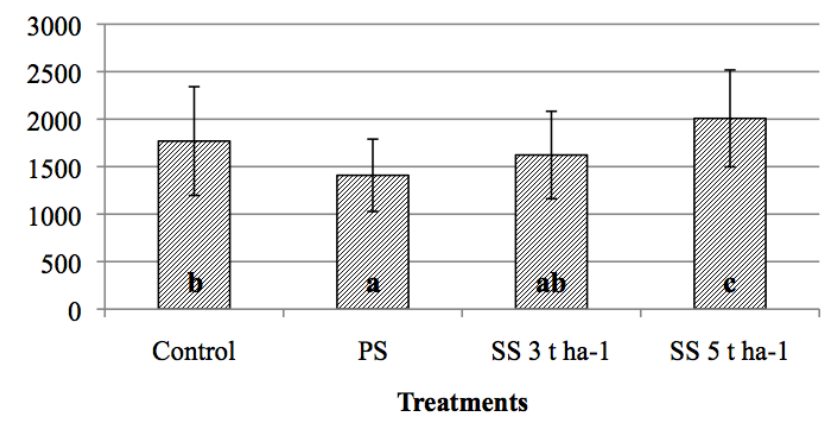

Figure 2. Oilseed rape grain yield and oil content. For each treatment, bars indicated by different letters are significantly different at $p<0.05$. PS: Powdered S; SS: Sieved S.

\section{Discussion}

The results obtained indicate that under the conditions of this study, the oxidation of sulphur and consequent soil acidification occurred rapidly. After establishment of the trial (October 2012), the $\mathrm{pH}$ of the leachates from the soils treated with sulphur and collected in the same month was clearly lower and the sulphate contents higher than in the control soil. Initially, the $\mathrm{pH}$ of the leachates from soils treated with the sieved $\mathrm{S}$ at the lower dose of $3 \mathrm{t} \mathrm{ha}^{-1}$ (SS3) was lower than in the other soils (Figure 1), but the $\mathrm{pH}$ then followed a similar pattern in all treatments. The sulphate content of the leachates collected on each of the dates was lower in the treatment 
with powdered $S$ than in the treatment with sieved S, even at the lowest dose of the latter (SS3). Overall this indicates that under the experimental conditions favouring oxidation, the $\mathrm{S}$ mobilized from the dose of 3 tha-1 ${ }^{-1}$ of the sieved $S$ was not lower than the amount mobilized from $1.5 \mathrm{t} \mathrm{ha}^{-1}$ of powdered $\mathrm{S}$, so that the increase in the dose should have been more than sufficient to compensate the lower reactivity of this form due to the larger particle size.

The conditions appear to have favoured the rapid oxidation and the immediate acidification effects. The moisture condition of the soils, close to field capacity, may also have contributed to the rapid oxidation of the sulphur, as S oxidation occurs fastest at field capacity (Miyamoto 1998). Jaggi et al. (2005) also found that oxidation of the elemental $S$ applied to the soil occurred very rapidly at $60 \%$ water-filled pore space (WFPS). This was very different from the behaviour reported by Byoung-Ho and Chung (2011), who stated that on mixing elemental $\mathrm{S}$ with soil, naturally occurring Thiobacillus oxidizes the $\mathrm{S}$ to form sulphuric acid, but that oxidation of $S$ is slow, and rapid changes in soil pH should not be expected. Ghani et al. (1994) found that in pastoral soils in New Zealand, first-time and repeated $\mathrm{S}^{0}$ applications after 1 year did not yield a higher oxidation rate. However, Li et al. (2005) reported that repeated application of $S^{0}$ increased the oxidation rate. The variability in the results reported in the literature indicate that oxidation of $S^{0}$ in soil depends on numerous factors that affect the process (Janzen and Bettany 1987). Thus, in areas with low precipitation watering should be adjusted to favour sulphur oxidation.

Ten months after application of the sulphur, the soil $\mathrm{pH}$ was only statistically significantly different in the soil treated with the lowest dose of sieved S (SS3), which implies greater longterm efficacy with the consequent effects on the subsequent harvest. On the other hand, the concentration of soluble sulphates in the solid phase of the soil was clearly related to the dose of sulphur added and was higher with the highest dose of sulphur used (Table 1).
In alkaline calcareous soils, a decrease in $\mathrm{pH}$ facilitates the dissolution of $\mathrm{CaCO}_{3}$ and the release of phosphates, leading to soil conditions that are more favourable for plant nutrient availability (DeLuca et al. 1989; Lindemann et al. 1991). This was also observed in the present study and was effective from the beginning of the experiment, as the phosphate contents of the leachates were higher in the soils that had received the highest doses of $S$ (treatments with sieved S). The powdered S did not appear to be more effective than the sieved $\mathrm{S}$, as indicated by the lack of significant differences between the concentrations of soluble phosphates in the solid phase of the control soil and the soils treated with powdered $S$ or the lower dose of sieved SS. Only the higher dose (SS5) yielded significant differences, indicating that it was the dose (rather than the form of $\mathrm{S}$ ) that determined the final state of the soil.

The foliar analysis revealed differences in $\mathrm{S}$ and Mo that help to elucidate the development of the soil acidification and its consequences for both the soil and the plant. Thus, the powdered form of $S$ gave rise to the highest concentration of $S$ in the plants. Sulphur is closely associated with $\mathrm{N}$, as the $\mathrm{S}$ deficiencies in plants reduce the formation of proteins and lead to the accumulation of non-protein nitrogen compounds (Pasricha and Fox 1993). In this case, the different $S$ contents did not affect the adsorption of $\mathrm{N}$, which was the same in all cases (Table 2). The high $\mathrm{pH}$ of the control soil facilitated adsorption of molybdenum (higher contents in plants) relative to plants grown in soils treated with $\mathrm{S}$, in which the $\mathrm{pH}$ values were lowest. Despite the different adsorption of nutrients by plants grown in the treated and untreated soils, this did not affect either grain or oil yields, which were highest in the soils treated with SS5. 


\section{Conclusions}

Analyses of the leachates, soil solid phase and plants during the oilseed rape growing cycle indicated that, under the study conditions, a dose of $3 \mathrm{t} \mathrm{ha}^{-1}$ of sieved sulphur (0.5-2 mm) was at least as effective as $1.5 \mathrm{t} \mathrm{ha}^{-1}$ of powdered sulphur for acidifying alkaline calcareous soils. Acidification occurred rapidly as the effects were apparent during the first crop cycle. Further studies should aim to determine the processes that affect sulphur oxidation in the long term.

\section{Acknowledgements}

This study was carried out with funding from the project FEDER-INTERCONECTA ESFER 2011CE-140 and as part of a collaborative agreement between REPSOL-RLESA and USC.

\section{REFERENCES}

- Bardsley CE, Landcaster JD. 1960. Determination of reserve sulfur and soluble sulfates in soils. Soil Soc Am Proc. 24:265-268.

- BOE. 1995. RD 2257/1994, de 25 de noviembre, por el que se aprueba los métodos oficiales de análisis de piensos o alimentos para animales y sus primeras materias. BOE núm. 52, de 2 de marzo de 1995. p. 71617237.

- Brady NC, Weil RR. 2010. Elements of the nature and properties of soils. 3rd Ed. New Jersey: PearsonPrentice-Hall. $614 \mathrm{p}$.

- Byoung-Ho K, Chung JB. 2011. Acidification and changes of mineral nutrient availability in soils amended with elemental sulphur. Korean J Soil Sci Fert. 44:22-28.

- Chapman HD, Pratt PF. 1961. Methods of analysis for soil, plants and waters. University of California, Division of Agricultural Sciences.

- DeLuca IH, Skogley EO, Engel RE. 1989. Band applied elemental sulphur to enhance the phyto availability of phosphorus in alkaline calcareous soils. Biol Fertil Soils 7:346-350.

- Fismes J, Vong PC, Guckert A, Frossard E. 2000. Influence of sulfur on apparent $\mathrm{N}$-use efficiency, yield and quality of oilseed rape (Brassica napus L.) grown on a calcareous soil. European Journal of Agronomy 12(2):127-141.

- Ghani A, Rajan SSS, Lee A. 1994. Enhancement of phosphate rock solubility through biological processes. Soil Biol Biochem. 26:127-136.

- Haneklaus S, Schnug E. 1991. Evaluation of the nutritional status of oilseed rape plants by leaf analysis. In: Proceedings of the 8th International Rapeseed Congress; 1991 Jul 9-11; Saskatoon, Saskatchewan, Canada. p. 536-541.

- Jackson GD. 2000. Effects of Nitrogen and Sulfur on Canola Yield and Nutrient Uptake. Agronomy Journal 92:644-649.

- Jaggi, RC, Aulakh MS, Sharma R. 2005. Impacts of elemental $S$ applied under various temperature and moisture regimes on $\mathrm{pH}$ and available $\mathrm{P}$ in acidic, neutral and alkaline soils. Biol Fertil Soils 41:52-58.

- Janzen HH, Bettany JR. 1987. The effect of temperature and water potential on sulfur oxidation in soils. Soil Science 144:81-89.

- Li ST, Lin B, Zhou W. 2005. Effects of previous elemental sulfur applications on oxidation of additional applied elemental sulfur in soils. Biol Fert Soils 42:146-152. 
- Lindemann WC, Aburto JH, Haffiner WM, Bono AA. 1991. Effect of sulphur sources on sulphur oxidation. Soil Sci Soc Am J. 55:85-90.

- MAGRAMA. 2012. Estadísticas Agrarias. Ministerio de Agricultura Alimentación y Medio Ambiente.

- Maluenda MJ [Internet]. 2014. Situación mundial del sector de la colza 2013/2014. [cited 2014 Oct 10]. Available from: http://www.agrodigital.com/Documentos/ colza201314.pdf.

- Miyamoto S. 1998. Use of acids and acidulants on alkali soils and water. In: Wallace A, Terry RE, editors. Handbook of soil conditioners substances that enhance the physical properties of soil. Part III. Mineral soil conditioners. New York: Marcel Dekker. p. 217-255.

- Olsen SR, Sommers LE. 1982. Phosphorus. In: Page AL, Miller RH, Deeney DE, editors. Methods of soil analysis. Part 2. 2nd ed. Madison, Wisconsin: ASASSSAJ. p. 403-430.

- Pasricha NS, Fox RL. 1993. Plant nutrient sulfur in the tropics and subtropics. Adv Agron. 50:209-269.

- Zhihui Y, Haneclaus S, Sing BR, Schung E. 2008. Effect of repeated application of elemental sulfur on microbial population, sulfate concentration, and $\mathrm{pH}$ in soils. Commun Soil Sci Plant Anal. 39:124-140. 